\title{
Trial Think About on Flexural Quality of Fortified Solid Pillars Remotely Reinforced with CFRP Sheets
}

\author{
M. Hema Priya, T.P. Meikandaan, Anitha.K
}

\begin{abstract}
Fiber Reinforced polymer are ordinarily utilized for the Strengthening of Reinforced Concrete Structures. In that CFRP assumes a crucial job in giving the quality, solidness and malleability of the Reinforced solid Structures when contrasted and different filaments like GFRP, steel and aramid strands. Concentrate on Flexural Strengthening of RC Beams with CFRP (Multiple Layers) is completed. The component of the pillar examples are 100mmx200mmx1500mm. Fortified solid pillars remotely reinforced with CFRP sheets were tried utilizing a symmetrical two point concentrated static stacking framework. Two pillars were tried for Control Beam for Flexural (FB) and two bars tried for it is preloading of $70 \%$ for FB. Furthermore, after that it is tried by CFRP base just various layers for preloading of $70 \%$ for $F B$. The outcome appear in expanding quality when contrasted with preloading of $70 \%$ for $F B$. Test information on burden, diversion and extreme heap of every one of the pillar were acquired. The heap versus avoidance bends were contrasted and Control Beam for Flexural (FB), Preloading $70 \% \mathrm{FB}$ and tried CFRP base numerous layer for preloading of $70 \%$ for $F B$. In this examination (CFRP) Carbon Fiber Reinforced Polymer gives apparent quality, solidness and malleability in flexure.
\end{abstract}

Key words: Flexure strengthening of beams and carbon fiber Reinforced polymer

\section{INTRODUCTION}

A fiber Reinforced polymer (CFRP) composite is described as a polymer (plastic) structure, either thermo set or thermoplastic, that is braced (joined) with a fiber or other sustaining material with a sufficient point of view extent (length to thickness) to give a distinguishable fortifying limit in any event one headings. FRP composites are one of a kind in connection to traditional improvement materials, for instance, steel or Aluminum. FRP composites are anisotropic (properties clear toward the associated weight) however steel or aluminum is isotropic (uniform properties all over, self-ruling of associated load). Along these lines, FRP composite properties are directional, inferring that the best

Revised Manuscript Received on July 22, 2019.

M. Hema Priya, Assistant Professor, Department of Civil Engineering, Bharath Institute Of Education And Research, Chennai , Tamil Nadumeihemapriya@gmail.com

T.P. Meikandaan, Associate Professor, Department of Civil Engineering, Bharath Institute Of Education And Research, Chennai , Tamil Nadu ganga_meik@yahoo.co.in

K.Anitha, Assistant Professor, Department of Civil Engineering, Bharath Institute Of Education And Research, Chennai , Tamil Nadu anithakrish26@yahoo.co.in mechanical properties are toward the fiber circumstance. Sustained strong structures may be exposed against dynamic breakdown in view of a nonappearance of reliable help. Carbon fiber reinforced polymer (CFRP) may be used to retrofit existing strengthened strong bars and give the missing intelligibility expected to restrict dynamic breakdown. A fiberReinforced polymer (FRP) composite is portrayed as a polymer (plastic) arrange, either thermo set or thermoplastic, that is invigorated (united with a fiber or other reinforcing material with a satisfactory point of view extent (length to thickness) to give an observable sustaining limit in any event one direction.Test Program

Table 1. Mix Proportion For $\mathbf{M}_{20}$

\begin{tabular}{|c|c|c|c|}
\hline Water & Cement & $\begin{array}{c}\text { Fine } \\
\text { Aggregate }\end{array}$ & $\begin{array}{c}\text { Coarse } \\
\text { Aggregate }\end{array}$ \\
\hline $\begin{array}{c}186 \\
\text { litre }\end{array}$ & $413.33 \mathrm{~kg}$ & $657 \mathrm{~kg}$ & $1140 \mathrm{~kg}$ \\
\hline 0.45 & 1 & 1.59 & 2.75 \\
\hline
\end{tabular}

The test program involves the casting of Specimens that are listed in the following steps below.

\section{EXPERIMENTAL INVESTIGATION}

The trial examination are directed by IS: $383-1970$ for the fine total and coarse total. The test directed are for fine total are explicit gravity, water assimilation, and for coarse total are explicit gravity, water retention, Impact test Crushing Test, Los Angel's Abrasion test appeared in table 2.

Table 2 Test on Fine and Coarse aggregate

\begin{tabular}{|l|l|l|}
\hline MATERIALS & PROPERTIES & VALUES \\
\hline \multirow{4}{*}{$\begin{array}{l}\text { FINE } \\
\text { AGGREGATE }\end{array}$} & Specific gravity & 2.60 \\
\cline { 2 - 3 } & Water absorption & $1.66 \%$ \\
\cline { 2 - 3 } & Grading zone & II \\
\hline \multirow{4}{*}{$\begin{array}{l}\text { COARSE } \\
\text { AGGREGATE }\end{array}$} & Specific gravity & 2.65 \\
\cline { 2 - 3 } & Water absorption & $0.80 \%$ \\
\cline { 2 - 3 } & Impact test & $200 \%$ \\
\cline { 2 - 3 } & Crushing test & $1950 \%$ \\
\cline { 2 - 3 } & $\begin{array}{l}\text { Los angel's } \\
\text { abrasion test }\end{array}$ & $6.25 \%$ \\
\hline
\end{tabular}

Table 3 Test on fresh concrete 
Trial Think About on Flexural Quality of Fortified Solid Pillars Remotely Reinforced with CFRP Sheets

\begin{tabular}{|l|c|}
\hline \multicolumn{1}{|c|}{ TEST } & VALUE \\
\hline Slump (mm) & $31 \mathrm{~mm}$ \\
\hline Compaction factor & 0.87 \\
\hline Vee-Bes (s) & 5.1 \\
\hline
\end{tabular}

A. Test On Hardened Concrete

Table 4. Compression Test On Concrete Cubes

\begin{tabular}{|l|l|}
\hline $\begin{array}{l}\text { Compressive } \\
\text { Strength,W/mm } \\
\text { (7 days) }\end{array}$ & $\begin{array}{l}\text { Compressive } \\
\text { Strength.W/ } / \mathrm{mm}^{2} \\
\text { (28 days) }\end{array}$ \\
\hline 1422 & 26.49 \\
\hline
\end{tabular}

Table 5. Tension Test On Concrete Cylinders

\begin{tabular}{|l|l|}
\hline $\begin{array}{l}\text { Teusile } \\
\text { Strength,N } / \mathrm{mm}^{2} \\
\text { (7 days) }\end{array}$ & $\begin{array}{l}\text { TeusileStrength, } \\
\mathrm{N} / \mathrm{mm}^{2} \\
(28 \text { days) }\end{array}$ \\
\hline 1.01 & 2.441 \\
\hline
\end{tabular}

\section{RESULTS AND DISCUSSION}

The Results and Discussion consist of the following things:

Table 5 Results of Control Beams

\begin{tabular}{|c|c|c|c|c|}
\hline \multirow{2}{*}{$\begin{array}{l}\text { Load } \\
\text { (Toune) }\end{array}$} & \multicolumn{2}{|c|}{ Control Beam 1} & \multicolumn{2}{|c|}{ Control Beam 2} \\
\hline & $\begin{array}{l}\text { Lvdt1 } \\
(\mathrm{mm})\end{array}$ & $\begin{array}{l}\text { Lvdt 2 } \\
(\mathrm{mm})\end{array}$ & $\begin{array}{l}\text { Lvdt 1 } \\
\text { (mm) }\end{array}$ & $\begin{array}{l}\text { Lvdt 2 } \\
\text { (mm) }\end{array}$ \\
\hline 0 & 0 & 0 & 0 & 0 \\
\hline 0.5 & 0.7 & 0 & 0.6 & 0.1 \\
\hline 1.0 & 09 & 0.3 & 09 & 0.3 \\
\hline 15 & 1.1 & 0.4 & 1.1 & 05 \\
\hline 2.0 & 1.4 & 0.6 & 13 & 0.6 \\
\hline 25 & 1.8 & 1.0 & 1.7 & 09 \\
\hline 3.0 & 2.4 & 15 & 23 & 1.4 \\
\hline 3.5 & 2.8 & 1.7 & 2.8 & 1.6 \\
\hline 4.0 & 3.4 & 23 & 35 & 2.2 \\
\hline 45 & 3.8 & 2.7 & 3.7 & 2.6 \\
\hline 5.0 & 45 & 3.4 & 4.4 & 33 \\
\hline 5.5 & 5.8 & 4.8 & 5.7 & 4.8 \\
\hline
\end{tabular}

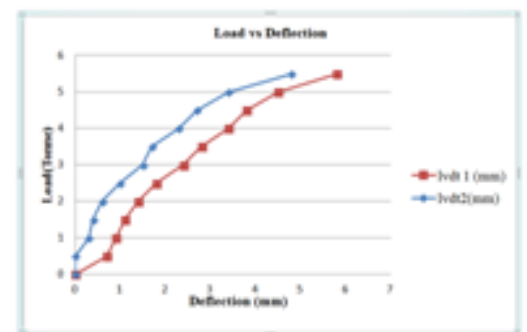

Figure 1. Load vs Deflection Graph for control Beam SB -1

Table 6 Pre loading for $70 \%$ FB-1

\begin{tabular}{|c|c|c|c|c|}
\hline & \multicolumn{2}{|c|}{ Fexure Beam 1 } & \multicolumn{2}{|c|}{$\begin{array}{c}\text { Fexure } \\
\text { Beam 2 }\end{array}$} \\
\hline $\begin{array}{c}\text { Load } \\
\text { (Tonnes) }\end{array}$ & Lvdt1(mm) & Lvdt2(mm) & 0 & 0 \\
\hline 0 & 0 & 0 & 0.5 & 0.5 \\
\hline 0.5 & 0.3 & 0.3 & 0.7 & 0.6 \\
\hline 1 & 0.4 & 0.4 & 1.1 & 1.0 \\
\hline 1.5 & 0.8 & 0.9 & 1.4 & 1.4 \\
\hline 2 & 1.1 & 1.2 & 2.0 & 1.8 \\
\hline 2.5 & 1.7 & 1.5 & 2.5 & 2.2 \\
\hline 3 & 2.2 & 2.0 & 2.9 & 2.6 \\
\hline 3.5 & 2.6 & 2.4 & 3.4 & 3.1 \\
\hline 4 & 3.2 & 3.0 & 3.5 & 3.2 \\
\hline 4.16 & 3.3 & 3.1 & 0 & 0 \\
\hline
\end{tabular}

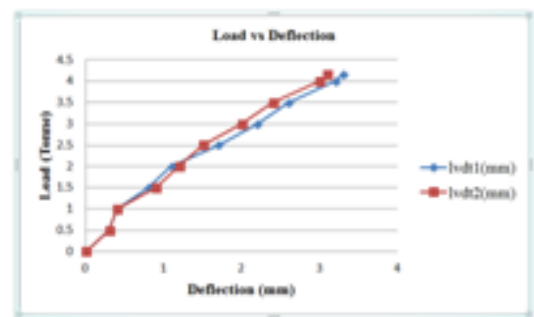

Figure 1 . Load vs Deflection Graph for Pre Loading 70\% FB-1

Table 7 -Test Result Of CFRP Bottom Wrapping Multiple Layer For Pre Loading For 70\% FB-I

\begin{tabular}{|c|c|c|c|c|}
\hline \multirow[t]{2}{*}{ Load(Tounes) } & \multicolumn{2}{|c|}{ Fexure Beam 1} & \multicolumn{2}{|c|}{ Fexure Beam 2} \\
\hline & Lvdt 1 (mm) & Lvdt 2(mm) & Lrdt $1(\mathrm{~mm})$ & Lvdt 2(mm) \\
\hline 0 & 0 & 0 & 0 & 0 \\
\hline 0.5 & 0.3 & 0.3 & 03 & 0.2 \\
\hline 1 & 0.4 & 0.4 & 0.4 & 03 \\
\hline 15 & 0.7 & 0.6 & 0.7 & 0.5 \\
\hline 2 & 111 & 10 & 10 & 0.8 \\
\hline 25 & 1.6 & 1.4 & 15 & 13 \\
\hline 3 & 2.1 & 1.8 & 20 & 1.7 \\
\hline 35 & 2.5 & 2.4 & 2.4 & 23 \\
\hline 4 & 3.1 & 29 & 3.0 & 2.8 \\
\hline 45 & 42 & 4.1 & 4.1 & 39 \\
\hline 5 & 5.1 & 49 & 49 & 4.7 \\
\hline 55 & 62 & 59 & 6.1 & 5.8 \\
\hline 6 & 8.0 & 78 & 79 & 7.7 \\
\hline 6.5 & 92 & 8.8 & 9.1 & 8.7 \\
\hline 7 & 10.4 & 9.8 & 103 & 9.6 \\
\hline 75 & 122. & 10.4 & 12.1 & 103 \\
\hline 8 & 145 & 13.8 & 145 & 135 \\
\hline
\end{tabular}

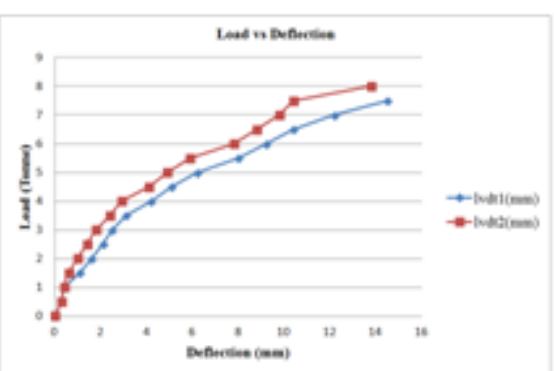

Figure 2. Load Vs Deflection Graph For Test Result Of CFRP Bottom Wrapping Multiple Layer For Preloading 70\% For FB-I

\section{A. Load At Initial Crack For SB}

Under two point static stacking of pillar examples, at every addition of burden, redirection and break advancement were watched .In $\mathrm{CB}$ inception for SB I, SB II,SB IIIof split

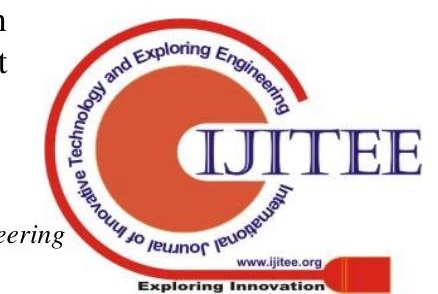


happens at a heap of 1.5Tonne.

\section{B. Result Of Ultimate Load For SB}

The Beam Specimen for CB for SB-I, SB-II, SB-III goes the ultimate load breaking point of 5.5 tonnes. After that the beam specimens SB I, SB II and SB III are then applied to the Pre Loading of $90 \%$ that is 4.95 Tonne. After then it was wrapped for CFRP U-wrapping Multiple layer for SB-I, SB-II,SB-III. The Test Result show the ultimate strength for SB-I, SB-II, SB-III were found to be 10 tonnes.

\section{Load At Initial Crack For FB}

Under two point static loading of beam specimens, at each increment of load, deflection and crack development were observed .In CB initiation for FB I, FB II,FB IIIof crack takes place at a load of 2.0 Tonne.

\section{Result Of Ultimate Load For FB}

The Beam Specimen for CB for FB-I, FB-II, FB-III goes a definitive burden limit of 6 tons. After that the pillar examples FB I, FB II and FB III are then connected to the Pre Loading of $70 \%$ that is 4.16 Ton. After then it was wrapped for CFRP U-wrapping Bottom just Multiple layer for FB-I, FB-II,FB-III. The Test Result demonstrate a definitive quality for FB-I, FB-II, FB-III were observed to be 8 tons.

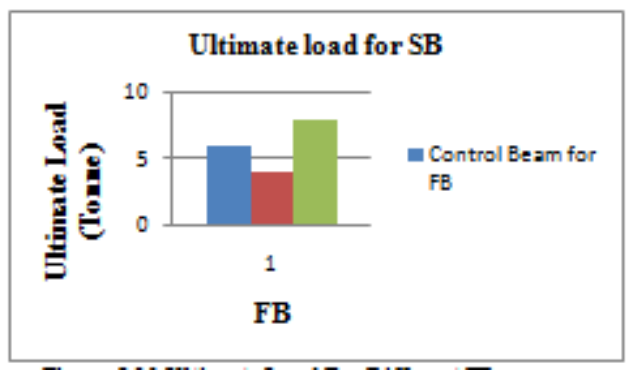

Figure 3 - Ultimate Load For Different FB

\section{CONCLUSION}

The Following conclusion is drawn from the test result: The Following end is drawn from the test outcome:

An) It is inferred that from Control Beam for FB Ultimate Breaking point is 6 Ton.

In the wake of Preloading $70 \%$ for FB of 4.16 Ton. At that point after CFRP base just wrapping various layer for Preloading 70\% for FB the test result for FB has been got 8 Ton.

In this manner after test result for CFRP U Wrapping Bottom just different layer for preloading $70 \%$ for $\mathrm{FB}$ it is expanded by 3.84 Ton.

B) The Deflection of Reinforced Concrete Beams increment with increment in flexible range.

Consequently from the Study on Flexural Strengthening of RC Beams with CFRP (Multiple layers) finish up the quality of the RC Beams in shear is expanded subsequent to wrapping Carbon Fiber Reinforced Polymer with numerous layers and furthermore the quality of the RC Beams in flexural is expanded in the wake of wrapping Carbon Fiber Reinforced Polymer with various layers.

\section{REFERENCES}

1. Iyappan L., Dayakar P., Identification of landslide prone zone for coonoortalukusing spatial technology, International Journal of Applied Engineering Research,V-9,I-22,PP-5724-5732,Y-2014.

2. Kumar J., Sathish Kumar K., Dayakar P.,Effect of microsilica on high strength concrete, International Journal of Applied Engineering Research,V-9,I-22,PP-5427-5432,Y-2014.

3. Dayakar P., Vijay Ruthrapathi G., Prakesh J., Management of bio-medical waste, International Journal of Applied Engineering Research,V-9,I-22,PP-5518-5526,Y-2014.

4. Swaminathan N., Dayakar P., Resource optimization in construction project, International Journal of Applied Engineering Research,V-9,I-22,PP-5546-5551,Y-2014.

5. Venkat Raman K., Dayakar P., Raju K.V.B.,An experimental study on effect of cone diameters in penetration test on sandy soil, International Journal of Civil Engineering and Technology, V-8,I-8,PP-1581-1588,Y-2017.

6. Saritha B., Chockalingam M.P.,Photodradation of malachite green DYE using TIO2/activated carbon composite,International Journal of Civil Engineering and Technology,V-8,I-8,PP-156-163,Y-2017

7. Shendge R.B., Chockalingam M.P., Saritha B., Ambica A.,Swat modelling for sediment yield: A case study of Ujjani reservoir in Maharashtra, India,International Journal of Civil Engineering and Technology,V-9,I-1,PP-245-252,Y-2018

8. Chockalingam M.P., Balamurgan V.,Modernisation of an existing urban road-sector in Chennai, a case study report,International Journal of Civil Engineering and Technology,V-8,I-8,PP-1457-1467,Y-2017

9. Saritha B., Chockalingam M.P.,Adsorption study on removal of basic dye by modified coconut shell adsorbent, International Journal of Civil Engineering and Technology,V-8,I-8,PP-1370-1374,Y-2017

10. Saritha B., Chockalingam M.P.,Adsorptive removal of heavy metal chromium from aqueous medium using modified natural adsorbent,International Journal of Civil Engineering and Technology,V-8,I-8,PP-1382-1387,Y-2017

11. Chockalingam M.P., Palanivelraja S.,Retrospective analysis of a theoretical model used for forecasting future air quality near the north Chennai thermal power plant,International Journal of Civil Engineering and Technology,V-8,I-8,PP-1457-1467,Y-2017

12. Saritha B., Chockalingam M.P.,Photodegradation of methylene blue dye in aqueous medium by $\mathrm{Fe}-\mathrm{AC} / \mathrm{TiO} 2$ Composite,Nature Environment and Pollution Technology,V-17,I-4,PP-1259-1265,Y-2018

13. Shendge R.B., Chockalingam M.P., Kaviya B., Ambica A.,Estimates of potential evapotranspiration rates by three methods in upper Bhima Basin, In Maharashtra, India,International Journal of Civil Engineering and Technology,V-9,I-2,PP-475-480,Y-2018

14. Shendge R.B., Chockalingam M.P.,The soil and water assessment tool for Ujjani Reservoir,International Journal of Mechanical Engineering and Technology,V-9,I-2,PP-354-359,Y-2018

15. Shendge R.B., Chockalingam M.P.,A review on soil and water assessment tool,International Journal of Mechanical Engineering and Technology,V-9,I-2,PP-347-353,Y-2018

16. Sachithanandam P., Meikandaan T.P., Srividya T.,Steel framed multi storey residential building analysis and design,International Journal of Applied Engineering Research,V-9,I-22,PP-5527-5529,Y-2014

17. Meikandaan T.P., Ramachandra Murthy A.,Study of damaged RC beams repaired by bonding of CFRP laminates,International Journal of Civil Engineering and Technology,V-8,I-2,PP-470-486,Y-2017

18. Meikandaan T.P., Ramachandra Murthy A.,Retrofittng of reinforced concrete beams using GFRP overlays,International Journal of Civil Engineering and Technology,V-8,I-2,PP-423-439,Y-2017

19. Meikandaan T.P., Ramachandra Murthy A.,Flexural behaviour of RC beam wrapped with GFRP sheets,International Journal of Civil Engineering and Technology,V-8,I-2,PP-452-469,Y-2017

20. Meikandaan T.P., Murthy A.R.,Experimental study on strengthening of rc beams using glass Fiber,International Journal of Civil Engineering and Technology,V-9,I-11,PP-959-965,Y-2018

21. Meikandaan T.P., Hemapriya M.,Use of glass FRP sheets as external flexural reinforcement in RCC Beam,International Journal of Civil Engineering and Technology,V-8,I-8,PP-1485-1501,Y-2017

22. Saraswathy R., Saritha B.,Planning of integrated satellite township at Thirumazhisai,International Journal of Applied Engineering 
Research,V-9,I-22,PP-5558-5560,Y-2014

23. Saritha B., Ilayaraja K., Eqyaabal Z.,Geo textiles and geo synthetics for soil reinforcement,International Journal of Applied Engineering Research,V-9,I-22,PP-5533-5536,Y-2014

24. Ambica A., Saritha B., Changring G., Singh N B., Rajen M., Salman Md.,Analysis of groundwater quality in and around Tambaram taluk, Kancheepuram district,International Journal of Civil Engineering and Technology,V-8,I-8,PP-1362-1369,Y-2017

25. Arunya A., Sarayu K., Ramachandra Murthy A., Iyer N.R.,Enhancement of durability properties of bioconcrete incorporated with nano silica,International Journal of Civil Engineering and Technology,V-8,I-8,PP-1388-1394,Y-2017

26. Ilayaraja K., Krishnamurthy R.R., Jayaprakash M., Velmurugan P.M., Muthuraj S.,Characterization of the 26 December 2004 tsunami deposits in Andaman Islands (Bay of Bengal, India),Environmental Earth Sciences,V-66,I-8,PP-2459-2476,Y-2012

27. Ilayaraja K.,Morphometric parameters of micro watershed in Paravanar sub-basin, Cuddalore District,International Journal of Civil Engineering and Technology,V-8,I-8,PP-1444-1449,Y-2017

28. Ilayaraja K., Singh R.K., Rana N., Chauhan R., Sutradhar N.,Site suitability assessment for residential areas in south Chennai region using remote sensing and GIS techniques,International Journal of Civil Engineering and Technology,V-8,I-8,PP-1468-1475,Y-2017

29. Ilayaraja K., Reza W., Kumar V., Paul S., Chowdhary R.,Estimation of land surface temperature of Chennai metropolitan area using Landsat images,International Journal of Civil Engineering and Technology,V-8,I-8,PP-1450-1456,Y-2017

30. Chitra R.,Experimental study on beam using steel fiber and latex,International Journal of Civil Engineering and Technology,V-8,I-8,PP-1395-1403,Y-2017

31. Chitra R.,Analysis of traffic and management at Kovilambakkam intersection,International Journal of Civil Engineering and Technology,V-8,I-8,PP-1433-1443,Y-2017

32. Aswathy M.,Experimental study on light weight foamed concrete,International Journal of Civil Engineering and Technology,V-8,I-8,PP-1404-1412,Y-2017

33. Aswathy M.,Wastewater treatment using constructed wetland with water lettuce (Eichornia Crasipies),International Journal of Civil Engineering and Technology,V-8,I-8,PP-1413-1421,Y-2017

34. Kiruthiga K., Anandh K.S., Gunasekaran K, Assessment of influencing factors on improving effectiveness and productivity of construction engineers, 2015, International Journal of Applied Engineering Research, V $-10, \mathrm{I}-17, \mathrm{p}-13849-13854$

\section{AUTHORS PROFILE}

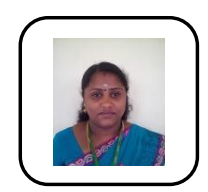

M.Hemapriya Assistant professor, Department of Civil Engineering, Bharath Institute of Higher Education and Research, Chennai, India

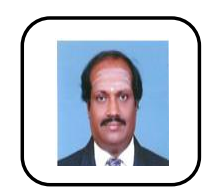

T.P. Meikandaan ,Associate professor, Department of Civil Engineering, Bharath Institute of Higher Education and Research, Chennai, India

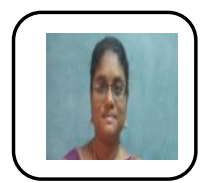

K.Anitha Assistant professor Department of Civil Engineering, Bharath Institute of Higher Education and Research, Chennai, India 